\title{
INTERPLANTING FLORAL RESOURCE PLANTS WITH VEGETABLE PLANTS ENHANCES BENEFICIAL ARTHROPOD ABUNDANCE IN A HOME GARDEN
}

\author{
Chrisdon B. Bonner ${ }^{1}$ \\ Eric J. Rebek ${ }^{2}$ \\ Janet C. Cole ${ }^{3}$ \\ Brian A. Kahn ${ }^{3}$ \\ Janette A. Steets ${ }^{1}$ \\ janette.steets@okstate.edu \\ ${ }^{1}$ Oklahoma State University \\ Department of Botany \\ 301 Physical Sciences \\ Stillwater, OK 74078
}

\author{
${ }^{2}$ Oklahoma State University \\ Department of Entomology and \\ Plant Pathology \\ 127 Noble Research Center \\ Stillwater, OK 74078 \\ ${ }^{3}$ Oklahoma State University \\ Department of Horticulture and \\ Landscape Architecture \\ 358 Agricultural Hall \\ Stillwater, OK 74078
}

Keywords: cowpea, herbivory, native ornamentals, natural enemies,
pollinators, polyculture, tomato

\begin{abstract}
We examined whether interplanting vegetable and ornamental flowering plants reduces herbivory and enhances photosynthetic rate, plant growth, natural enemy abundance, and pollinator visitation relative to monoculture plantings. We found no evidence of physiological or growth costs due to growth in polyculture. Herbivore damage to plants did not differ with planting regime. Natural enemies occurred in greater abundance in polycultures compared to monocultures. Pollinator diversity was enhanced in some polyculture plots. We suggest that interplanting vegetable and flowering ornamental plants at small spatial scales may improve plant health and reproduction through natural pest control and a diversified pollinator pool.

\section{INTRODUCTION}

Habitat manipulation strategies regulate pest populations in managed landscapes by enhancing the abundance of arthropod predators and parasitoids (natural enemies) by provisioning additional plant-based resources (i.e., nectar, pollen, alternative prey, or shelter) (Rebek et al. 2005, 2006; Fiedler et al. 2008). These same strategies may also have beneficial effects for pollinator abundance and diversity due to an increased abundance of flowering plants in the managed landscape (Tuell et al. 2008). A common habitat manipulation strategy that often benefits natural enemies and pollinators in managed landscapes is the use

of polycultures, the cultivation of multiple plant species together.

Relative to most monoculture plantings, polycultures offer beneficial arthropods (i.e., natural enemies and pollinators) greater floral resources (i.e., nectar and pollen rewards) throughout the growing season, alternative prey, and increased habitat structure and availability of nesting sites (Andow and Risch 1985; Andow 1991; Landis et al. 2000, 2005; Hooks and Johnson 2003). Polycultures may also provide improved microhabitats for plants and arthropods, such as increased shade and protection from wind, relative to most monocultures (Andow 1991; Landis et al. 2000). In addition to enhancing beneficial
\end{abstract}


arthropod abundance, polycultures often support lower pest arthropod abundance than monocultures (Kloen and Altieri 1990; Nicholls and Altieri 2004; Ponti et al. 2007; Isaacs et al. 2009).

At small spatial scales, such as those of home gardens, polycultures are a particularly attractive alternative to cultivation techniques that require heavy pesticide applications to control pest arthropods. Home gardeners commonly use pesticides to control pest arthropods (Sadof et al. 2004); in the United States, $16 \%$ of all insecticides applied annually are used in residential gardens and lawns (U. S. EPA 2011). Widespread residential pesticide use poses significant threats to human health and the environment by increasing the incidence of pesticide poisonings (Pimentel et al. 1992; U. S. EPA 2009), reducing stream and ground water quality (Cohen 2010), and killing non-target organisms (e.g., insect pollinators, aquatic fauna) (Johansen and Mayer 1990; Pimentel et al. 1992; Relyea 2009). Effective alternatives to residential pesticide applications are needed to improve safety, minimize effects on nontarget organisms, and reduce environmental contamination.

To date, most studies of polyculture techniques have examined the role of plantbased resources for natural enemy ecology and in regulating natural enemy populations (Fiedler et al. 2008). What remains less well studied is whether planting polyculture gardens of vegetable and flowering ornamental plants has other beneficial effects for garden crops. We hypothesized that plants grown in polycultures will have higher rates of pollinator visitation as well as higher abundance of natural enemies relative to monoculture plantings. With an increase in natural enemy abundance (Landis et al. 2000), we hypothesized that plants grown in polycultures will experience reduced rates of herbivory compared to monoculture plantings. Herbivore damage is known to adversely affect photosynthesis and plant growth (Crawley 1997; Zangerl et al. 2002). Thus, if growing plants in polycultures reduces herbivory, then we hypothesized that plants in polycultures will have higher rates of photosynthesis and growth relative to monoculture plantings. Accordingly, the first objective of this study was to examine whether polycultures of vegetable and flowering ornamental plants reduce herbivory relative to monocultures. Our second objective was to examine whether polycultures of vegetable and ornamental plants enhance photosynthetic rate and growth relative to monocultures. Our third objective was to examine whether polycultures enhance pollinator visitation and pollinator diversity relative to monoculture plantings. Our fourth objective was to examine whether polycultures enhance natural enemy abundance relative to monocultures.

\section{MATERIALS AND METHODS}

\section{Garden Design}

We conducted this study at The Botanic Garden at Oklahoma State University (Stillwater, OK; 3607'08.6" N, 9706'04.5" W) from April 23, 2009, to September 1, 2009. Seven plant species were included in the study. Four native, commonly cultivated ornamental species were largeflower tickseed (Coreopsis grandiflora Hogg ex Sweet 'Early Sunrise'), purple coneflower (Echinacea purpurea (L.) Moench), blanketflower (Gaillardia x grandiflora Van Houtte 'Arizona Sun'), and goldenrod (Solidago sp. 'Wichita Mountains'). Three commonly cultivated vegetable species were cilantro (Coriandrum sativum L.), tomato (Solanum lycopersicum L. 'Mountain Fresh Plus'), and cowpea (Vigna unguiculata (L.) Walp 'Early Scarlet'). We chose vegetable species that would be typical of an Oklahoma or southern U.S. home garden (Hillock and Simons 2002). While tomato and cowpea are self-fertile, visitation by insects, primarily bees, improves 
reproductive success (Free 1993). All flowering plants included in our study provide nectar and pollen to beneficial arthropods, and the chosen species overlap in blooming period, ensuring a continuous supply of floral resources.

We used a randomized complete block design consisting of four blocks of nine experimental plots each. Plots within each block were randomly assigned to one of nine planting treatments. Each plot measured $1 \mathrm{~m} \times 2 \mathrm{~m}$ and was separated from other plots by a $1 \mathrm{~m}$ mulched border. All plots and borders were kept free of weeds by hand pulling. All plots were composed of native soil (Norge loam, finesilty, mixed, thermic Udic Paleustolls) and were provided supplemental water by drip irrigation. Plants were not fertilized, as adequate plant mineral nutrients were available from fertilization of previous trials. The nine planting treatments included monocultures of each of the plant species (seven plots) and two different polycultures to add more generality to our results.

One polyculture consisted of largeflower tickseed, goldenrod, cilantro, and tomato (one plot; 'Polyculture One'), and the other polyculture consisted of purple coneflower, blanketflower, goldenrod, and cowpea (one plot; 'Polyculture Two'). Monocultures of the four ornamental species were planted with 18 plants/plot on April 23-24, 2009, using established nursery stock. Tomato monocultures were planted on April 25, 2009, using established nursery stock and included two plants/plot; plants were centered in each plot and spaced $60 \mathrm{~cm}$ apart within the row. We seeded the monocultures of cilantro on April 25, 2009, at a density of 240 seeds per $1 \mathrm{~m}$ row, with six rows per plot. Monocultures of cowpea were seeded on May 22, 2009, at a density of 20 seeds per $1 \mathrm{~m}$ row, with two rows per plot. We later thinned cowpea to 10 plants per $1 \mathrm{~m}$ row where stands permitted. Within Polyculture One plots, we planted six largeflower tickseed, three goldenrod, two tomatoes, and seeded one row of cilantro at a density of 240 seeds per $1 \mathrm{~m}$ row. We planted goldenrod and largeflower tickseed on April 23-24, 2009. We planted tomatoes and seeded cilantro on April 25, 2009.

Within Polyculture Two plots, we planted three purple coneflower, three blanketflower, three goldenrod, and seeded two rows of cowpea at a density of 20 seeds per $1 \mathrm{~m}$ row. We later thinned cowpeas to 10 plants per row where stands permitted. We planted cowpeas on May 22, 2009, and purple coneflower, blanketflower, and goldenrod on April 23-24, 2009. The plant species were sown at densities recommended by the Oklahoma Cooperative Extension Service. Different species were not planted on the same date because 1) a planting date of April 25 was too early for cowpea, which was directseeded and requires warm soils for proper germination; and 2) ornamental plants (purple coneflower, blanketflower, and goldenrod) were planted at later dates as a result of plant availability. We did not observe any shading of later-planted species by those planted earlier.

Cilantro and goldenrod did not establish in monoculture or polyculture. In addition, several plots of the other plant species did not establish well. Thus, our analyses included four plots of largeflower tickseed, three plots of purple coneflower, four plots of blanketflower, three plots of tomato, two plots of cowpea, two plots of Polyculture One, and three plots of Polyculture Two.

\section{Herbivory}

To determine whether planting regime influenced rates of herbivory, we quantified leaf damage on two plants of each species per plot twice during the growing season (June and July). For each plant, we estimated herbivore damage on one standard module per plant (Turcotte et al. 2014) by counting the total number of leaves and the number of leaves with 
herbivore damage on the module (i.e., branch, rosette). The plant module varied for each species based on plant morphology; we counted all of the leaves on purple coneflower, only the leaves of the basal rosette on blanketflower, the leaves of one stem on largeflower tickseed, and the leaves of one lower branch on tomato and cowpea. For these same plants, we then recorded the number of leaves on the module damaged by herbivory. We calculated percent of damaged leaves for each plant as the total number of damaged leaves divided by the total number of leaves per module. We quantified herbivore damage on plants rather than inventorying herbivores, as herbivore damage represents a more comprehensive temporal perspective on herbivory in these plots; however, common herbivores in these crops included aphids (family Aphididae), tomato hornworms (Manduca quinquemaculata), flea beetles (family Chrysomelidae, tribe Alticini), squash bugs (Anasa tristis), cucumber beetles (Acalymma sp. and Diabrotica sp.), and spider mites (family Tetranychidae).

\section{Plant Height and Photosynthetic Measurements}

To determine whether planting regimes (i.e., monoculture versus polyculture) affected traits related to plant health, we quantified height to the nearest centimeter and measured light-saturated photosynthetic rate using an infrared gas analyzer (LI-6400, LI-COR, Inc.; Lincoln, NE). Photosynthetic rate was quantified for one newly expanded leaf from each of two plants per species per plot. We recorded these measurements twice during the growing season (July and August). Each month, all measurements were taken within a three-day period between 09:0013:00 CDST on sunny days. We standardized leaf chamber conditions with a temperature of $30^{\circ} \mathrm{C}$, photosynthetically active radiation (PAR) at $1500 \mu \mathrm{mol} \mathrm{m}^{-2} \mathrm{~s}^{-1}$, and $\mathrm{CO}_{2}$ concentration of $400 \mathrm{ppm}$. Because calculations of photosynthetic rate are based in part on leaf surface area, we collected leaves that did not fill the entire leaf chamber and later determined leaf surface area using image analysis software (ImageJ, National Institutes of Health Freeware; Bethesda, MD).

\section{Pollinator Abundance and Composition}

Throughout the summer, we observed insect visitation to flowers within our experimental plots during $15 \mathrm{~min}$ observation periods. Observations were limited to sunny days when the wind was calm. Throughout the summer, observation times varied throughout the day (between 07:00-17:00 CDST) to capture a wider diversity of insect visitors. On a given day, we rotated observations among experimental plots (Kearns and Inouye 1993). During each 15 min observation period, we recorded insect visitation at the flower or inflorescence level, recording visits to all open flowers or inflorescences on several plants within each experimental plot. Observations of tomato and cowpea were conducted at the flower level; whereas, observations of all other plant species were conducted at the inflorescence level. Within a plot, we observed as many flowers or inflorescences on as many plants as was possible at one time, including simultaneous observations of several plant species in polycultures. We recorded floral visitors from four insect orders: beetles (Coleoptera); wasps, honey bees, bumble bees, and small-bodied bees (Hymenoptera); true flies (Diptera); and butterflies (Lepidoptera).

We observed monoculture plots for a total of $7.75 \mathrm{~h}$ over the course of the experiment. Total duration of observations varied among species in monocultures (tomato, $1.25 \mathrm{~h}$; cowpea, $1 \mathrm{~h}$; purple coneflower, $1.5 \mathrm{~h}$; largeflower tickseed, $1.5 \mathrm{~h}$; blanketflower, $2.5 \mathrm{~h}$ ). We observed polyculture plots for a total of $9 \mathrm{~h}$ over the

Chrisdon B. Bonner, et al. 
course of the experiment. As with monocultures, the total duration of observations varied among species in polycultures (tomato, $1.25 \mathrm{~h}$; cowpea, $1.75 \mathrm{~h}$; purple coneflower, $1.5 \mathrm{~h}$; largeflower tickseed, 2.5 h; blanketflower, 3 h).

\section{Natural Enemy Abundance and Composition}

We sampled natural enemies using $7.5 \mathrm{x}$ $13 \mathrm{~cm}$ yellow sticky cards (Hoback et al. 1999) every two weeks throughout the growing season, for a total of seven sample dates over the course of the experiment. Around mid-morning on selected days, two sticky cards per plot were placed $1 \mathrm{~m}$ above ground level on stakes and left for $48 \mathrm{~h}$. We used a compound stereomicroscope to identify and sort specimens from the sticky cards into twelve groups of arthropods: spiders (order Araneae), rove beetles (family Staphylinidae), lady beetles (family Coccinellidae), hover flies (family Syrphidae), tachinid flies (family Tachinidae), minute pirate bugs (family Anthocoridae), nabid bugs (family Nabidae), other predators, parasitic wasps, other wasps, bees, and other pollinators.

Arthropods were sorted and identified to family level and/or functional group (e.g., parasitic wasps) for comparison among plots. We defined total natural enemy abundance as the sum of individuals of all arthropod classes found on the sticky cards, excluding bees and other pollinators from the total. As yellow sticky cards are not effective at sampling the pollinator community (Kearns and Inouye 1993), we did not analyze the bee/other pollinator data gathered from the sticky cards.

\section{Flowering Phenology}

For comparison with natural enemy abundance, we recorded flowering phenology weekly as the number of open flowers (tomato and cowpea) or inflorescences (purple coneflower, blanketflower, and largeflower tickseed) for three plants per species per plot.

\section{Statistical Analyses}

To examine whether planting regime (monoculture versus polyculture), species, or their interaction influenced percent of leaves with herbivore damage, height, or light-saturated photosynthetic rate, we performed separate repeated measures analyses of variance (ANOVA) for each variable (PROC GLM, SAS Institute; Cary, NC). The model for these analyses included block as a random effect and planting regime, plant species, and their interaction as fixed effects. Prior to analysis, we tested all response variables for normality and found that the variables met ANOVA assumptions without data transformation.

We performed $G$-tests (Zar 1999) separately for each plant species to determine whether pollinators under- or over-visited flowers (or inflorescences) on plants grown in monoculture relative to those in polyculture. Visits to flowers (or inflorescences) were considered independent events and the unit of sampling was individual flowers (or inflorescences) within a plot. Observations of tomato and cowpea were performed at the flower level. Analyses of members of Asteraceae (purple coneflower, blanketflower, and largeflower tickseed) were performed at the inflorescence level. For each 15 min observation period, we calculated visitation rate per plant species as the total number of visitors divided by the total number of flowers (or inflorescences). Visitation rate was not normally distributed, even after data transformation; thus, we performed nonparametric Kruskal-Wallis tests separately for each plant species (PROC NPAR1WAY, SAS Institute; Cary, NC) to determine whether planting regime influenced total visitation rate of all floral visitors.

To determine whether planting regime, sampling date, or their interaction 
influenced total abundance of natural enemies, we performed repeated measures ANOVA (PROC MIXED, SAS Institute; Cary, NC). The model for this analysis included block as a random effect and planting regime, sampling date, and their interaction as fixed effects. When we detected a significant main effect of species or a significant interaction between plant species and planting regime, we used Tukey post hoc comparisons to test for differences among means. To determine whether there was a relationship between total natural enemy abundance and flowering phenology (i.e., number of open flowers) of each plant species over the course of the experiment, we used a non-parametric Spearman rank correlation (PROC CORR, SAS Institute; Cary, NC).

\section{RESULTS}

\section{Herbivory}

Leaf damage did not differ between plants grown in monoculture versus those grown in polyculture gardens across the growing season $\left(F_{1,15}=0.71, P=0.41\right)$ (Fig. 1; monoculture vs. polyculture mean leaf damage \pm standard error (SE): $16.12 \%$ $\pm 2.27 \%$ vs. $9.46 \% \pm 2.49 \%$ leaves damaged). All species responded similarly in terms of leaf damage to planting regime across the growing season $\left(F_{4,15}=0.69\right.$, $P=0.61)$. As expected, leaf damage differed across plant species $\left(F_{5,15}=29.41\right.$, $P<0.0001$; see Fig. 1).

\section{Plant Height and Photosynthetic Measurements}

As expected, plant species differed in height and photosynthetic rate (Height: $F_{4,16}=49.90, P<0.0001 ;$ Photosynthetic rate: $F_{4,15}=31.69, P<0.0001$ ) (Fig. 2). Plant height and photosynthetic rate were not significantly affected by planting regime (i.e., monoculture versus polyculture) (analyses not shown; all $P>0.10$ for planting regime effect) and all species responded similarly in terms of these traits to planting regime (analyses not shown; all $P>0.10$ for interaction term).

\section{Pollinator Abundance and Composition}

Of the two vegetable plant species (cowpea and tomato) for which we conducted pollinator observations, we only recorded floral visitors to cowpeas; we observed no insects visiting tomato flowers. Coleoptera were observed more frequently on flowers of cowpea plants grown in polyculture than those grown in monoculture $(G=3.85, P<0.05)$, but the opposite pattern occurred for Diptera $(G=47.3, P<0.0001)$. The pattern of visitation to cowpeas by Hymenoptera and by other floral visitors did not differ significantly with planting regime (all $P>0.05)$. Insects from three orders (i.e., Coleoptera, Diptera, and Hymenoptera) were observed visiting cowpea flowers in monoculture gardens; whereas, we observed insects from four orders (i.e., Coleoptera, Diptera, Hymenoptera, and Lepidoptera) visiting cowpea flowers in polyculture plantings (Fig. 3A). Thus, the diversity of floral visitors to cowpea was greater in polycultures compared to monocultures (see Fig. 3A).

Hymenoptera were observed more frequently visiting inflorescences of purple coneflower plants in polycultures than those in monoculture $(G=18.6, P<0.001)$, but the opposite pattern was found for Coleoptera $(G=4.1, P<0.05)$. Visitation by Lepidoptera and Diptera to purple coneflower did not differ significantly between planting regimes $(P>0.05$; Fig. 3B). Lepidoptera were observed more frequently visiting inflorescences of blanketflower plants grown in polyculture than those in monoculture $(G=3.94$, $P<0.05)$. The proportion of visits to inflorescences by Coleoptera, Diptera, and Hymenoptera did not differ significantly between blanketflower planting regimes (all $P>0.05$; Fig. 3C). The proportion of visits 
to inflorescences by four taxa (Coleoptera, Diptera, Hymenoptera, and Lepidoptera) did not differ significantly between largeflower tickseed planting regimes (all $P>0.05$; Fig. 3D).

Although total visitation rate across all insect orders did not differ significantly between planting regimes for any plant species (purple coneflower: $X^{2}{ }_{1}=0.0064$, $P>0.10$; largeflower tickseed: $X^{2}{ }_{1}=0.6433$, $P>0.10$; blanketflower: $X^{2}{ }_{1}=0.1491$, $P>0.10$; cowpea: $X^{2}{ }_{1}=3.0, P=0.0833$ ), cowpea growing in monocultures tended to experience a higher visitation rate compared to cowpeas grown in polycultures (Fig. 4).

\section{Natural Enemy Abundance and Composition}

Total abundance of natural enemies was significantly higher in polycultures compared to monocultures $\left(F_{7,102}=4.34\right.$,
$P=0.0003$; mean natural enemies/plot/sampling date for monocultures vs. polycultures \pm SE: 25.78 \pm 1.24 vs. $28.31 \pm 2.84)$. In addition, Polyculture Two yielded 30\% higher natural enemy abundance than Polyculture One. Parasitic wasps were by far the most common group of natural enemies in all planting regimes (Fig. 5). Total abundance of natural enemies differed across the season $\left(F_{6,102}=68.08, P<0.0001\right)$; natural enemy abundance was highest in late spring, rapidly declined in mid-June, rebounded in mid-July, and then decreased for the remainder of the growing season (Fig. 6). There was a significant interaction between planting regime and sampling date for natural enemy abundance $\left(F_{42,102}=1.53\right.$, $P=0.0434)$ 


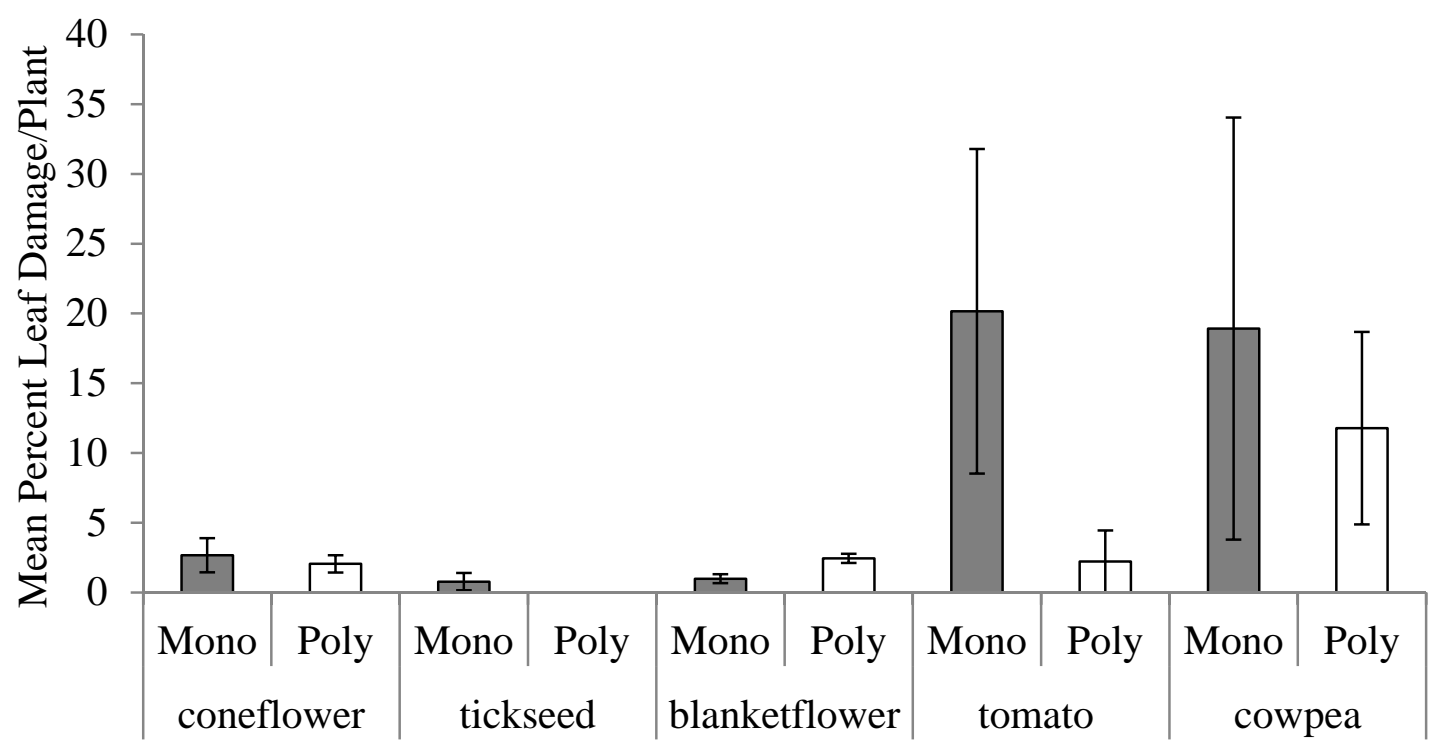

Figure 1A Mean herbivory ( $\pm 1 \mathrm{SE}$ ) of purple coneflower, largeflower tickseed, blanketflower, tomato, and cowpea grown in monoculture (solid bar) and polyculture (open bar), during June 2009, in Stillwater, Oklahoma.

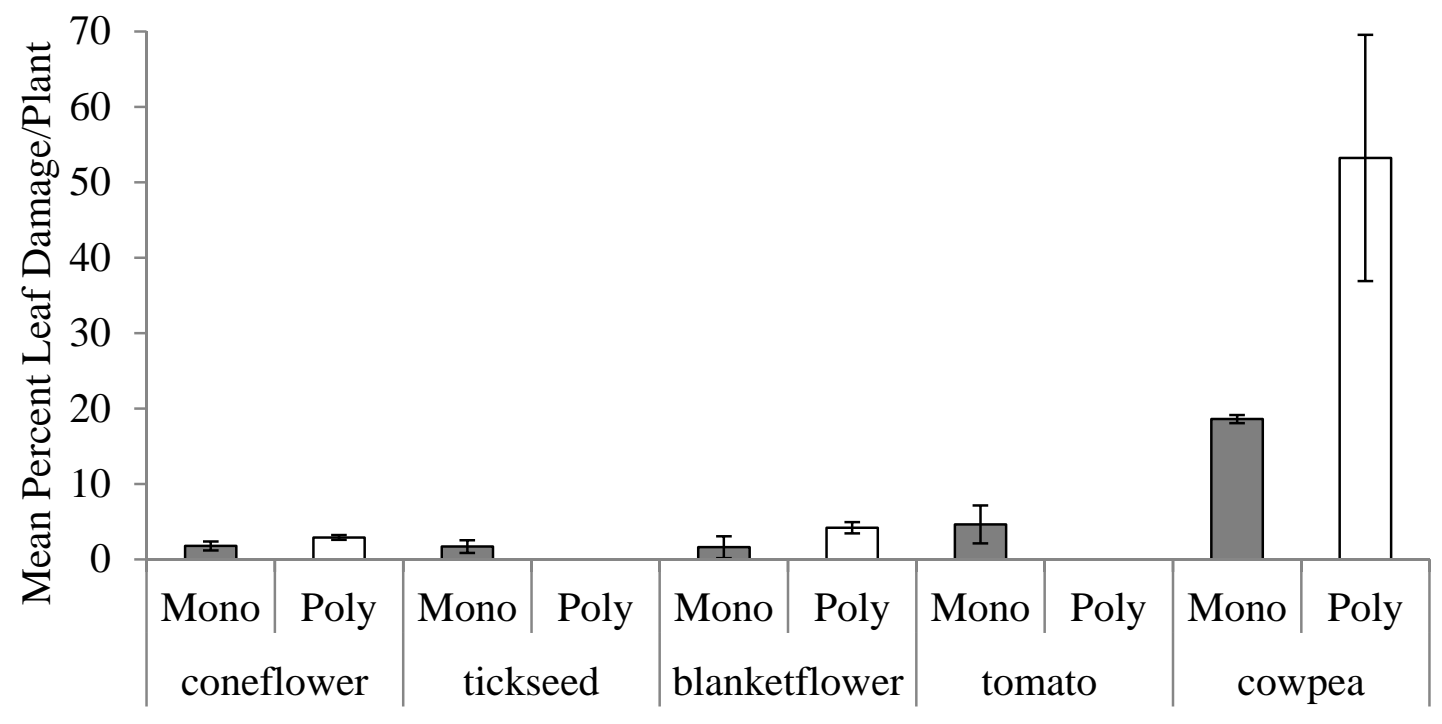

Figure 1B Mean herbivory ( \pm 1 SE) of purple coneflower, largeflower tickseed, blanketflower, tomato, and cowpea grown in monoculture (solid bar) and polyculture (open bar), during July 2009, in Stillwater, Oklahoma. 

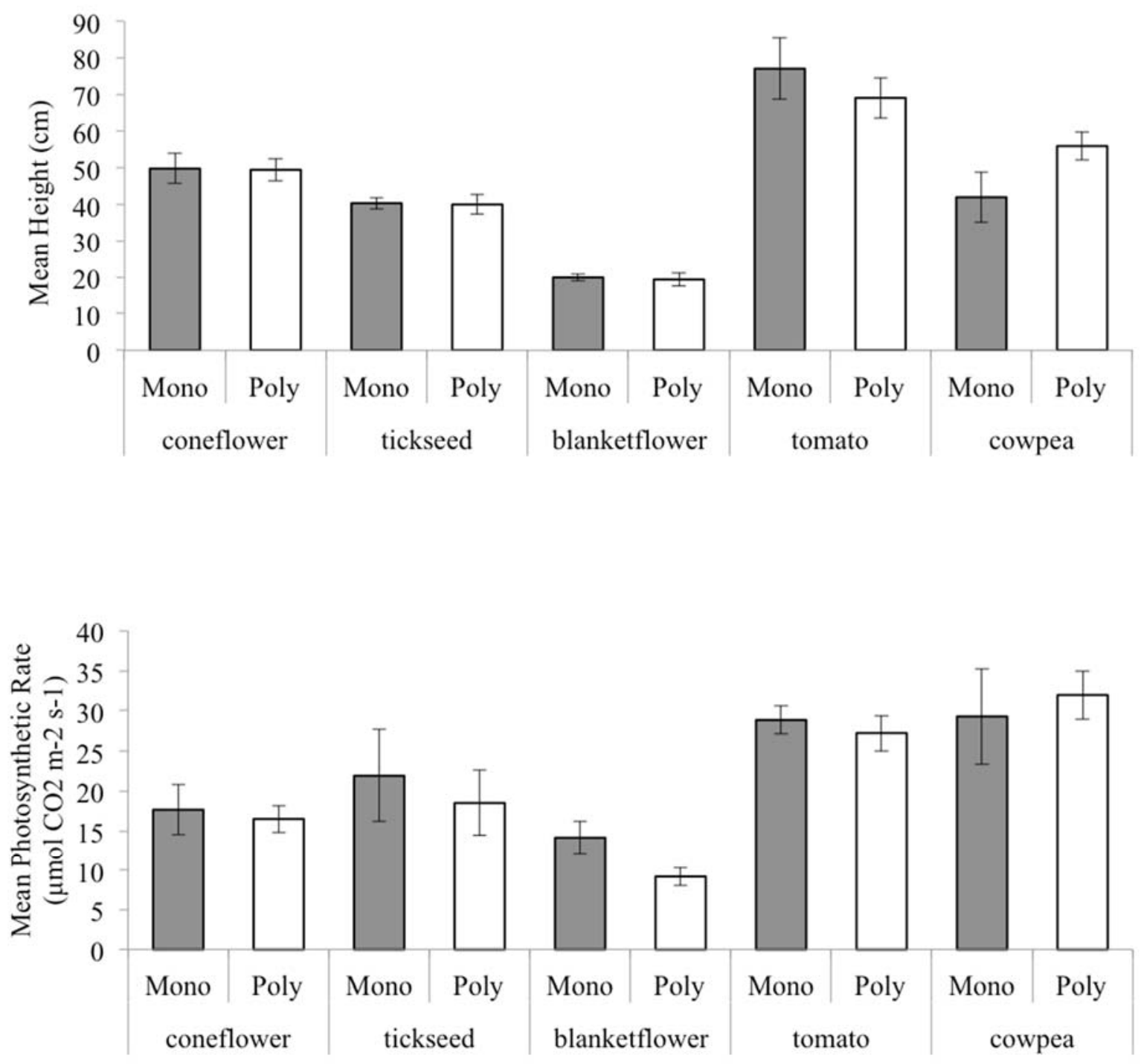

Figure 2 Mean plant height and light-saturated photosynthetic rate $( \pm 1 \mathrm{SE})$ of ornamentals (coneflower, tickseed, and blanketflower) and vegetables (tomato and cowpea) grown in monoculture (solid bar) and polyculture (open bar), during July 2009, in Stillwater, Oklahoma. August data not shown. 


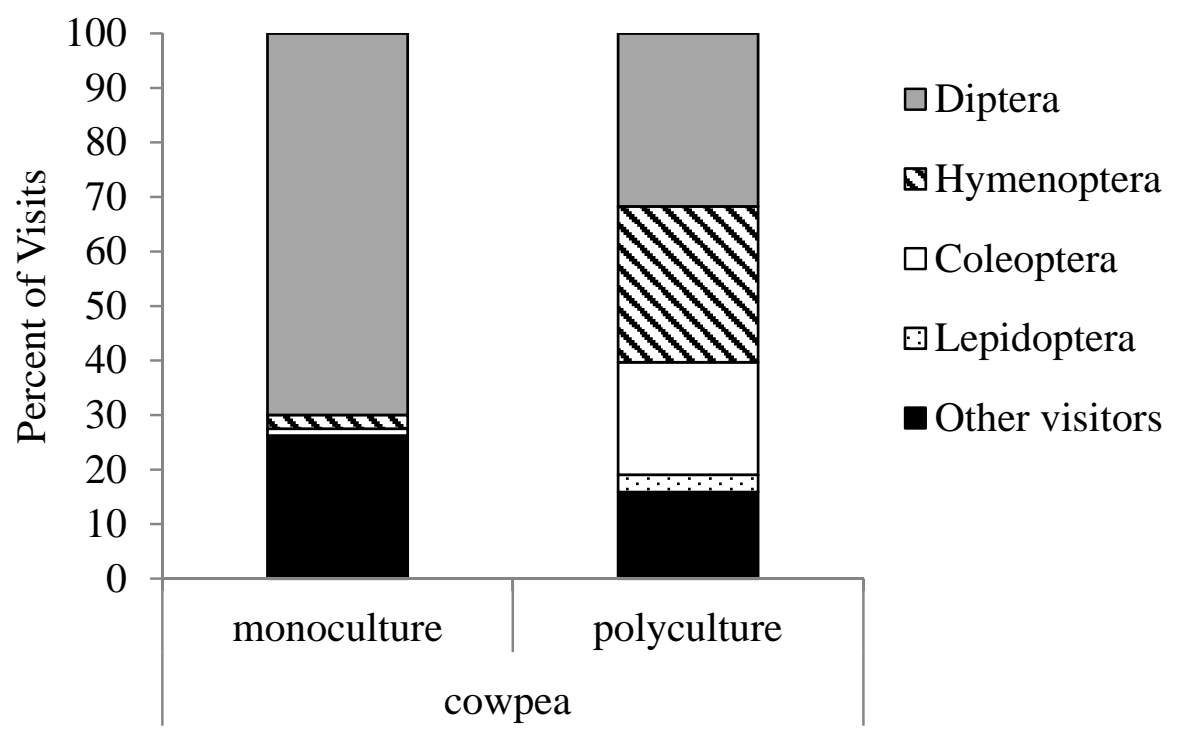

Figure 3A Percent of floral visits from four insect orders to cowpea grown in monoculture and polyculture, April 23-September 1, 2009, in Stillwater, Oklahoma.

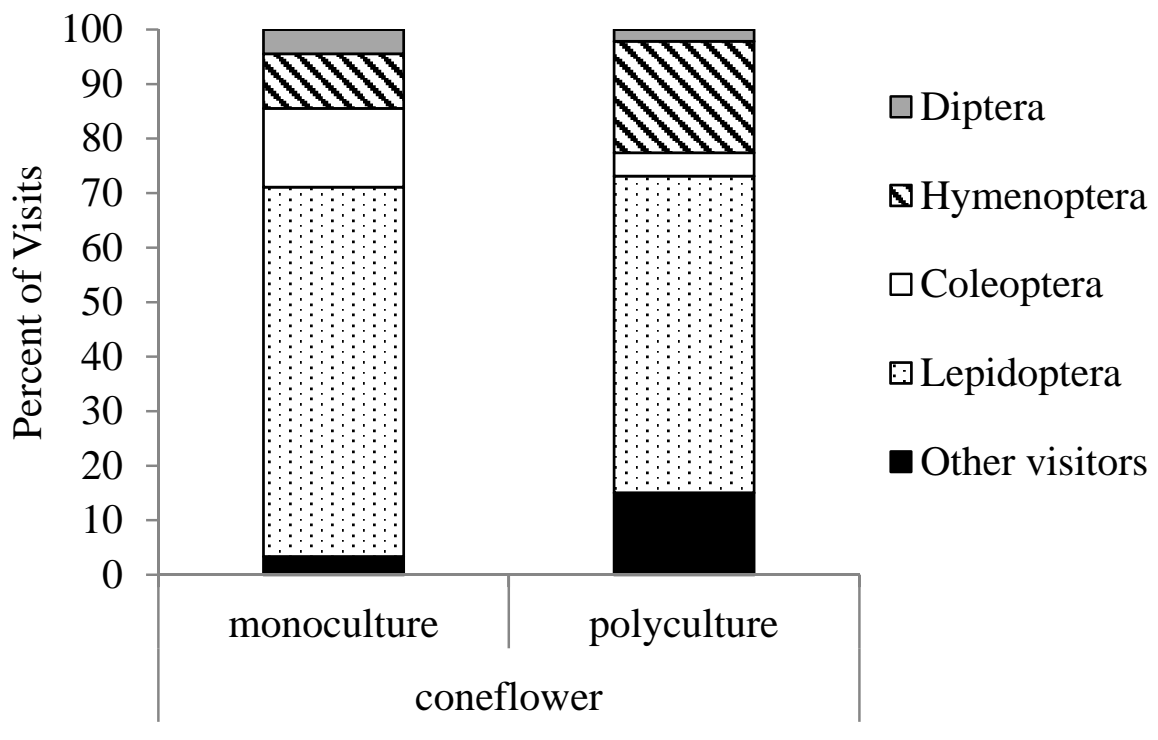

Figure 3B Percent of floral visits from four insect orders to purple coneflower grown in monoculture and polyculture, April 23-September 1, 2009, in Stillwater, Oklahoma. 


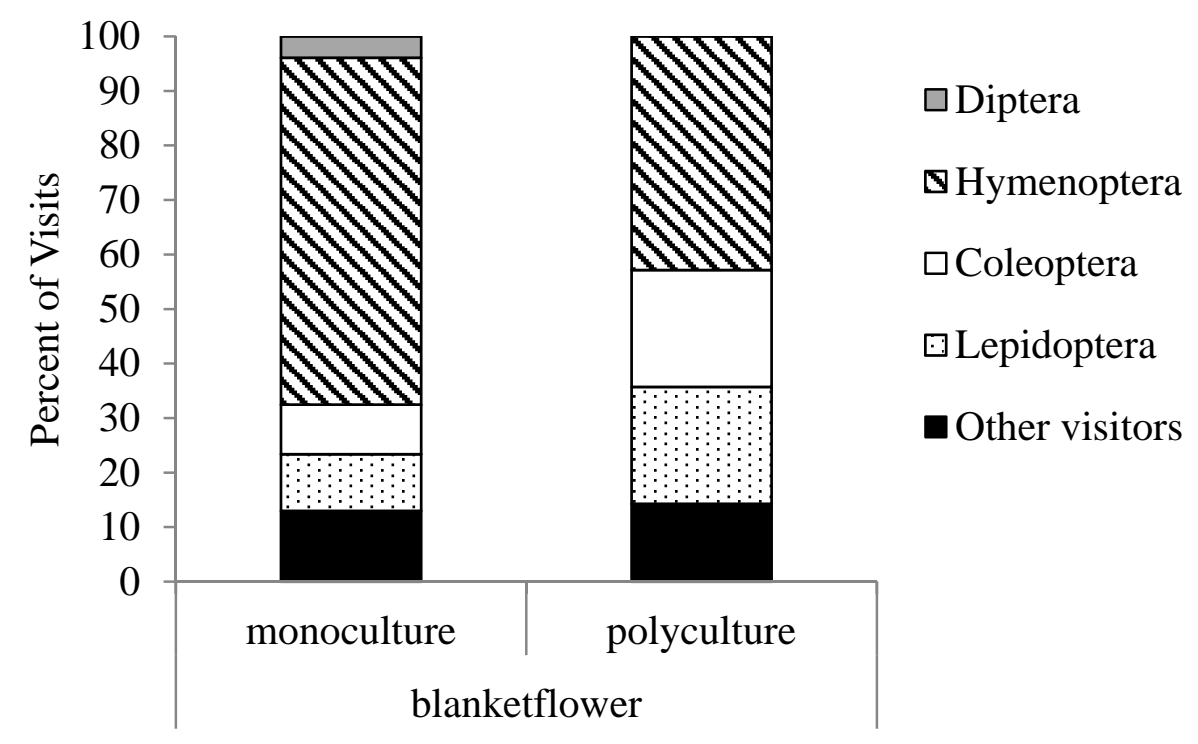

Figure 3C Percent of floral visits from four insect orders to blanketflower grown in monoculture and polyculture, April 23-September 1, 2009, in Stillwater, Oklahoma.

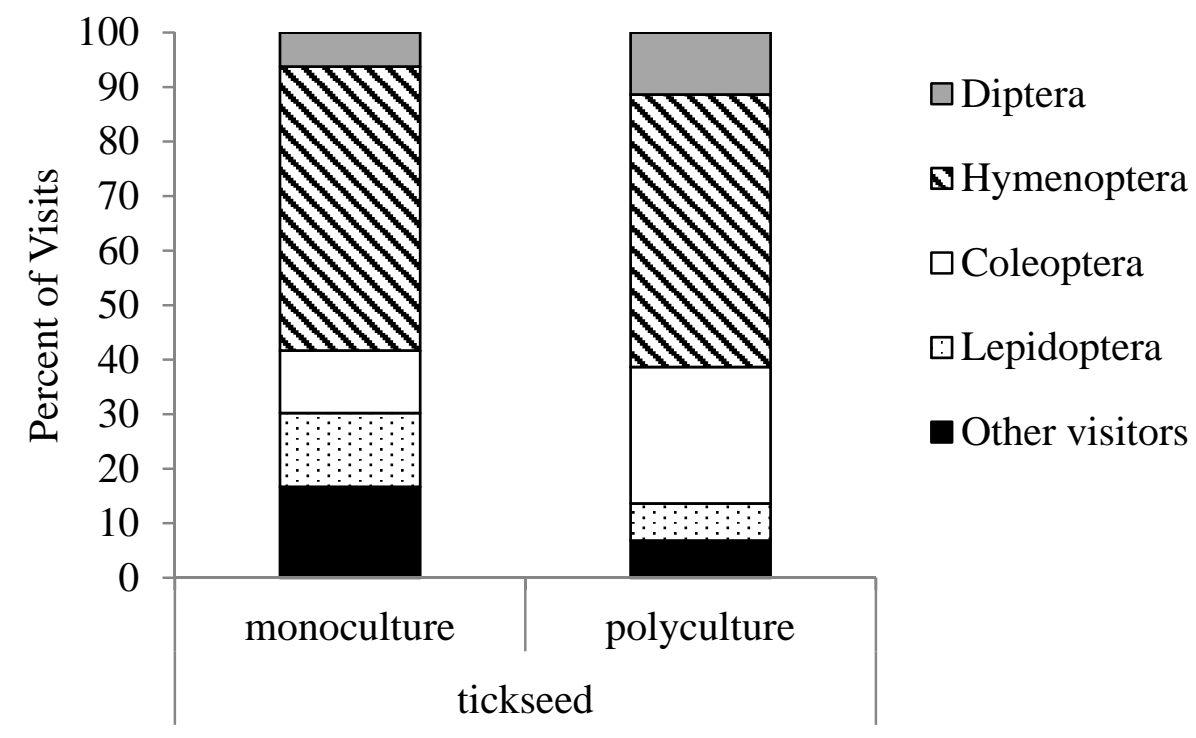

Figure 3D Percent of floral visits from four insect orders to largeflower tickseed grown in monoculture and polyculture, April 23-September 1, 2009, in Stillwater, Oklahoma. 


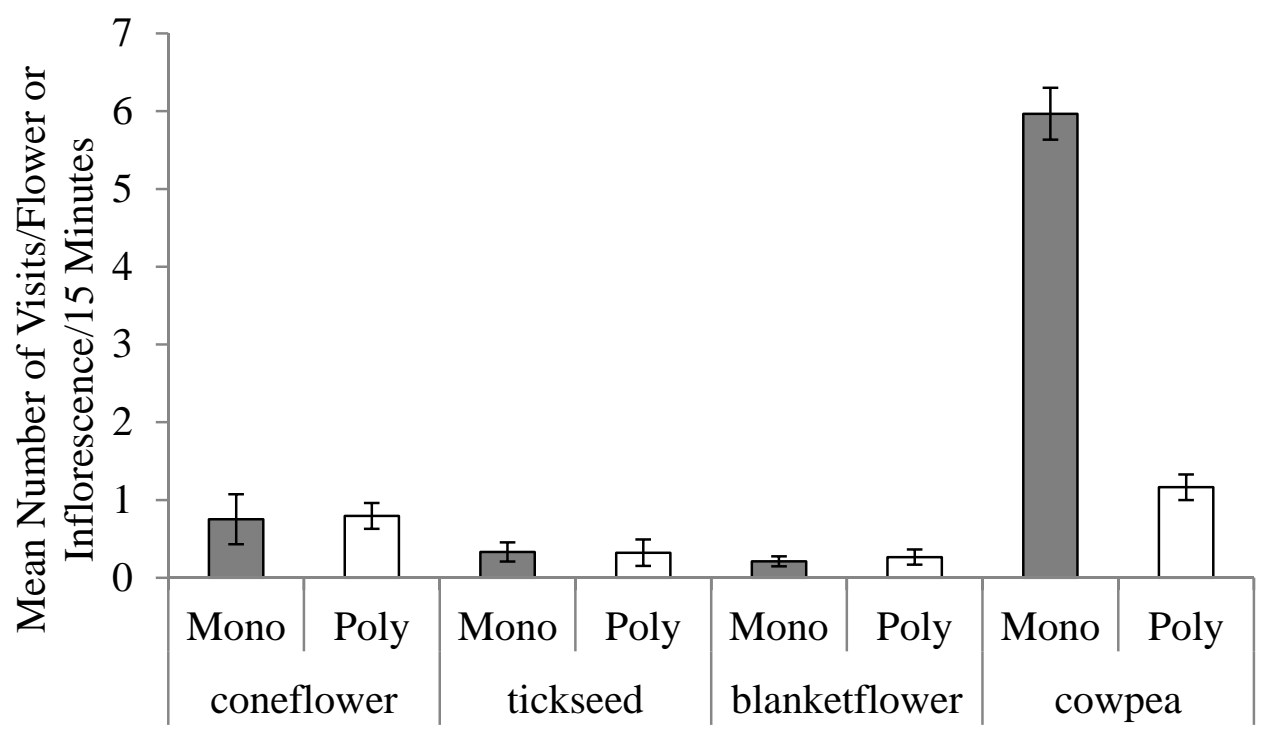

Figure 4 Mean visitation rate $( \pm 1 \mathrm{SE})$ of floral visiting insects to purple coneflower, largeflower tickseed, blanketflower, and cowpea grown in monoculture and polyculture, April 23-September 1, 2009, in Stillwater, Oklahoma.

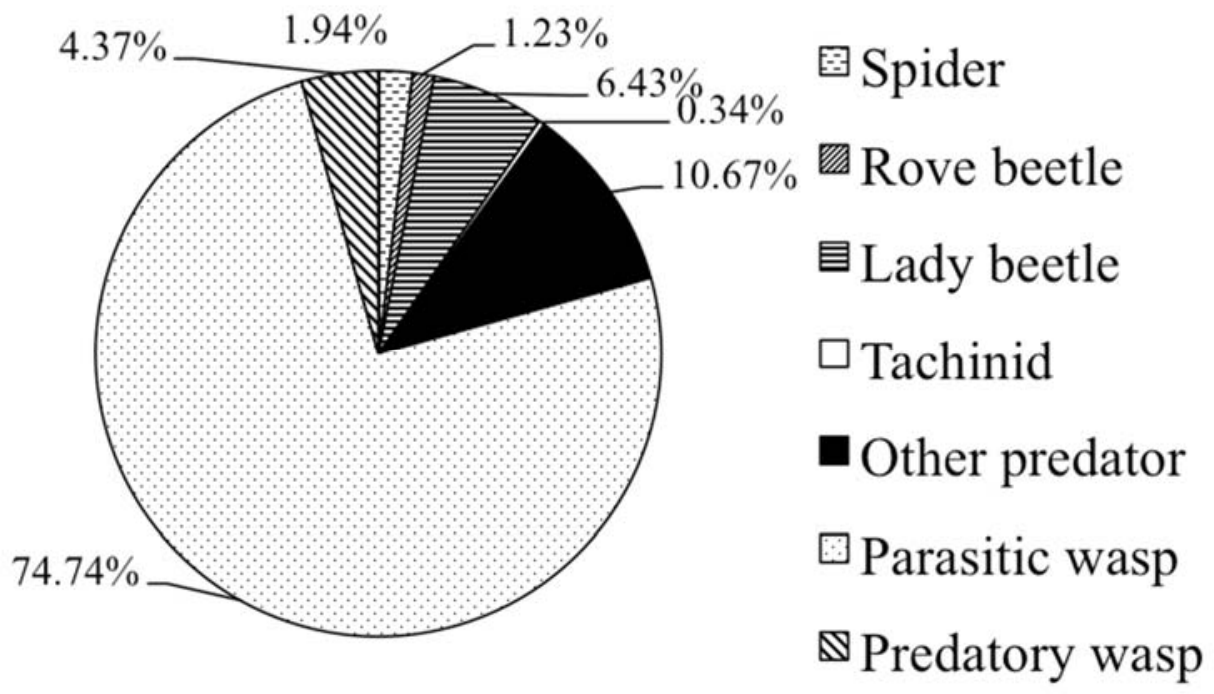

Figure 5A Percent abundance of seven natural enemy groups sampled using yellow sticky cards across all monocultures, April 23-August 25, 2009, in Stillwater, Oklahoma. 


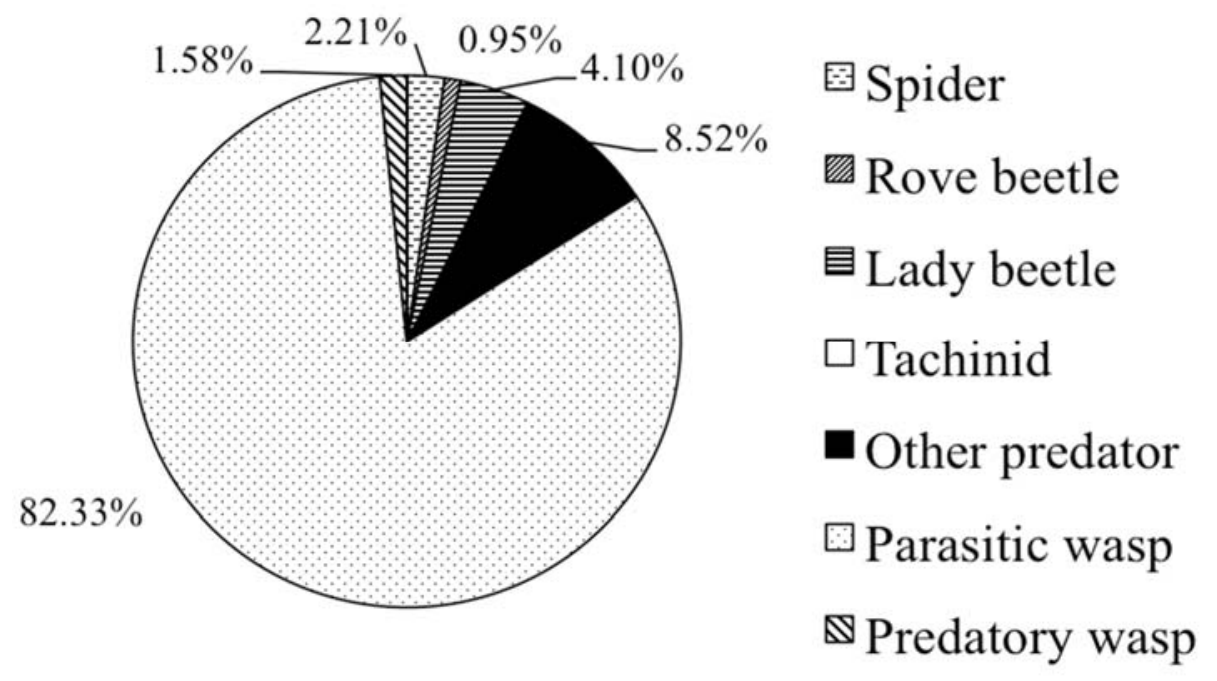

Figure 5B Percent abundance of seven natural enemy groups sampled using yellow sticky cards across Polyculture One, April 23-August 25, 2009, in Stillwater, Oklahoma.

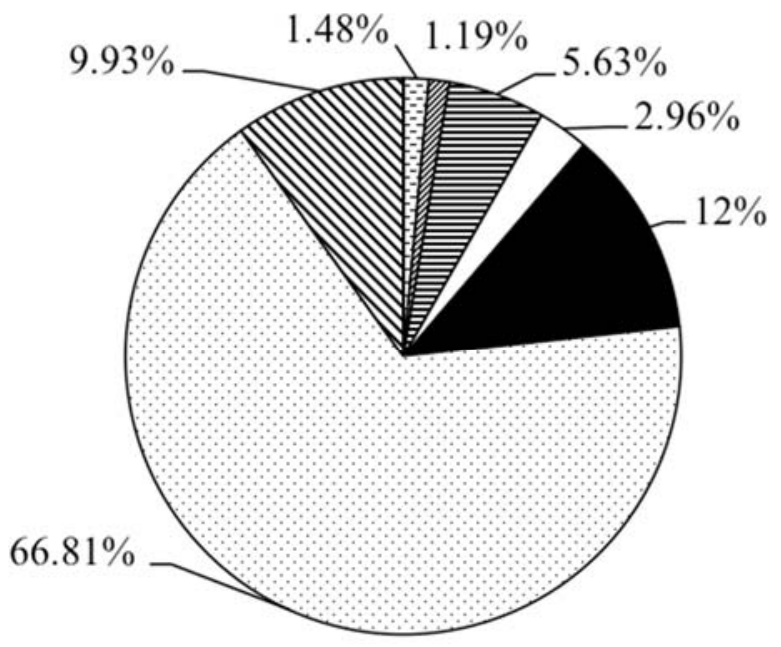

图Spider

Rove beetle

目 Lady beetle

$\square$ Tachinid

- Other predator

Parasitic wasp

$\mathbb{Q}$ Predatory wasp

Figure 5C Percent abundance of seven natural enemy groups sampled using yellow sticky cards across Polyculture Two, April 23-August 25, 2009, in Stillwater, Oklahoma. 


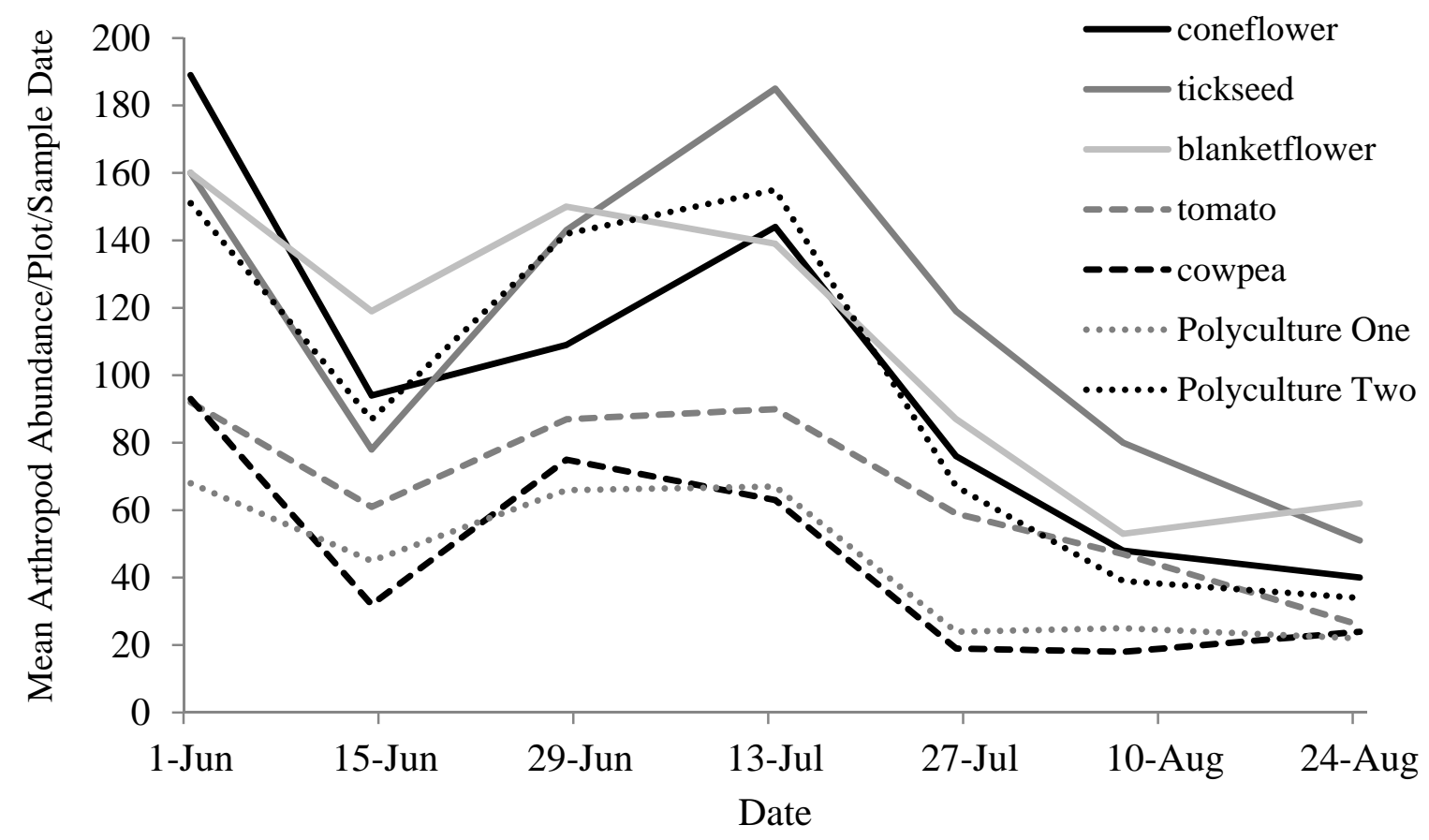

Figure 6 Mean total natural enemy abundance per plot for each plant species grown in monoculture, Polyculture One, and Polyculture Two, June 2-August 25, 2009, in Stillwater, Oklahoma.

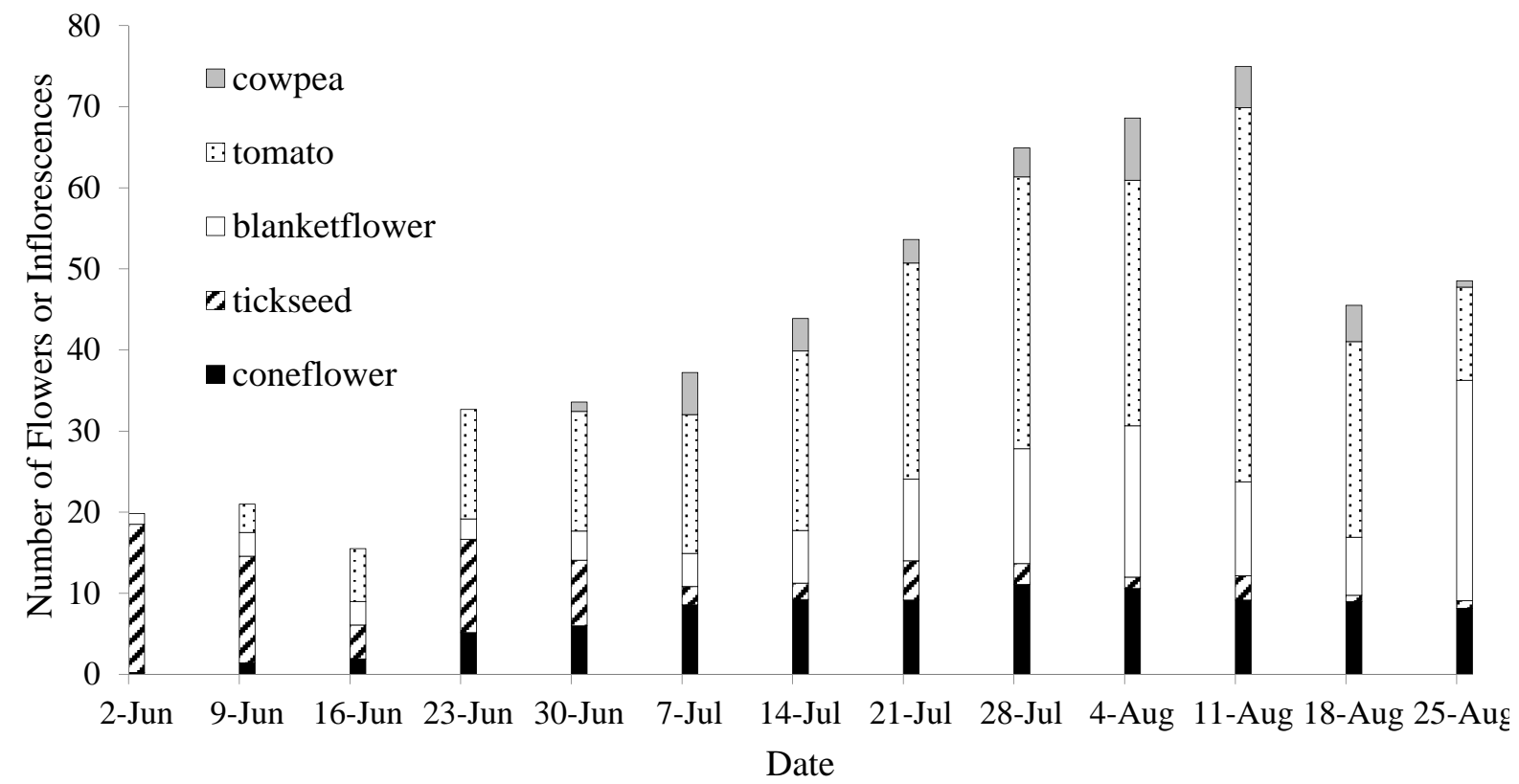

Figure 7 Number of open flowers or inflorescences per plant for purple coneflower, largeflower tickseed, blanketflower, tomato, and cowpea, June 2-August 25, 2009, in Stillwater, Oklahoma, pooled across monocultures and polycultures. 


\section{Flowering Phenology and Natural Enemy Abundance}

Flowering phenology was similar between monoculture and polyculture plantings for all species; therefore, all treatments were pooled for the illustration of peak flowering times (Fig. 7). Most species (except those species belonging to Asteraceae) exhibited a bimodal peak in flowering; the first peak in flowering occurred from late June to early July and the second from early to mid-August. Both peaks coincided with rainfall events. Two of the ornamental species (purple coneflower and blanketflower) exhibited peak flowering in mid to late August. The other ornamental species, largeflower tickseed, exhibited peak flowering in early June.

The abundance of blanketflower inflorescences was negatively correlated with natural enemy abundance $\left(r_{\text {Spearman }}=-0.79, N=7, P=0.03\right)$. Natural enemy abundance was not correlated with the abundance of flowers or inflorescences of any other plant species (Table 1).

Table 1 Spearman-rank correlation between total natural enemy abundance and flower or inflorescence abundance of five plant species grown in monoculture and polyculture, June 2 -August 25, 2009, in Stillwater, Oklahoma; * $P<0.05$.

\begin{tabular}{|c|c|}
\hline Species & Correlation Coefficient \\
\hline \hline Cowpea & -0.55858 \\
\hline Tomato & -0.42857 \\
\hline Blanketflower & $-0.78571 *$ \\
\hline Coneflower & -0.39286 \\
\hline Tickseed & 0.32143 \\
\hline
\end{tabular}

\section{DISCUSSION}

Our study demonstrated that natural enemy abundance is higher in polycultures than in monocultures. This finding, in conjunction with similar findings by other researchers (Kloen and Altieri 1990; Andow 1991; Rebek et al. 2005; Ponti et al. 2007), suggests that growing vegetable plants in polyculture with flowering ornamental species is an effective habitat management strategy to increase abundance of natural enemies at small spatial scales, such as those found in home gardens.

There are a number of mechanisms by which polycultures may promote natural enemy abundance. First, the addition of flowering ornamental plants may provide additional pollen and nectar resources and/or may attract alternative prey species, all of which serve as food sources for natural enemies (Landis et al. 2000; Rebek et al. 2005; Isaacs et al. 2009). Second, the ornamental plants may provide a hospitable microclimate and shelter (i.e., refugia) to natural enemies. Refugia are essentially sites where temperature, humidity, light intensity, and other abiotic conditions are at optimal levels for survival of natural enemies. Refuge plants may also harbor alternative prey species for both immature and adult natural enemies (Frank 2010), leading to 
increased abundance of natural enemies. Given that we did not detect a significant positive correlation between flowering phenology and natural enemy abundance (see Table 1), the availability of floral resources to natural enemies is likely to be less important than the availability of refugia in determining habitat quality for these arthropods at small spatial scales, such as those found in home gardens. However, future work is needed to determine the mechanism(s) by which polycultures of vegetable and ornamental plants enhance natural enemy abundance.

In addition to supporting higher natural enemy abundance, polycultures have been shown to reduce pest arthropod abundance and improve control of key plant pests compared with monocultures (Kloen and Altieri 1990; Rebek et al. 2006; Ponti et al. 2007). Thus, we expected higher rates of herbivory in monoculture compared to polyculture. However, we failed to detect significant differences between monoculture and polyculture for any plant species. Differences may have been more apparent with other vegetable crops. For example, Ponti et al. (2007) found that broccoli (Brassica oleracea L. Italica group) polycultures benefited from reduced herbivore abundance compared to broccoli grown in monocultures.

We predicted that reduced herbivory experienced by plants grown in polyculture would lead to improved health in polyculture plants compared to those in monocultures; however, we found no significant differences in height or photosynthetic activity between plants grown in monoculture and plants grown in polyculture. The lack of differences suggests that no physiological cost exists to vegetables grown in polycultures with ornamental plants at the planting densities and arrangements chosen for this study compared to vegetables grown in monocultures.
Previous work has demonstrated that greater diversity of flowering plants leads to greater diversity of pollinating insects (Potts et al. 2003, 2004). In line with this past work, we found that cowpea grown in polyculture had an additional order of insect floral visitors (Lepidoptera) compared with cowpea grown in monoculture (see Fig. 3A). Higher diversity of pollinators is linked to improved pollinator services and increased plant reproductive success (Albrecht et al. 2012). Future research should investigate whether greater diversity of pollinating insects to cowpeas grown in polyculture results in increased crop yields relative to monoculture plantings.

Our results did not support the hypothesis of higher pollinator visitation rates to plants grown in polyculture vs. monoculture. In fact, we observed the opposite trend for cowpeas. Because largebodied bees are the primary pollinators of cowpea (Free 1993), this tendency toward an increased visitation rate, mostly from true flies (Diptera), does not necessarily translate to an increase in the number of successful pollinations compared to plants in polyculture, as the pollination efficiency of true flies to cowpea is not known.

\section{Conclusions}

Our findings provide evidence that a habitat manipulation strategy in which vegetable and ornamental plants are grown in polyculture has beneficial effects for some crops, including species typically grown in home gardens. Polycultures support a greater abundance of natural enemies. Thus, diversifying plantings to include both vegetable and ornamental species may provide an alternative means to control pest populations, which has important implications for home gardeners. Furthermore, the home gardener may see additional benefits of a diversified garden, including a more diverse pollinator assemblage. 


\section{ACKNOWLEDGEMENTS}

This project was funded by the Institute for Sustainable Environments at Oklahoma State University (OSU). We thank The Botanic Garden at OSU for providing facilities, as well as Daniel Valdez, Senior Agriculturist at The Botanic Garden at OSU, for assistance in maintaining irrigation to garden plots. We thank Derek Barchenger, Cristina Carballo, and Cameron Goforth for assistance with fieldwork. We also thank Matthew Allen, Lou Anella, Lynn Brandenberger, and Kristen Baum for insightful comments that improved this manuscript.

\section{LITERATURE CITED}

Albrecht, M., B. Schmid, Y. Hautier, and C.B. Muller. 2012. Diverse pollinator communities enhance plant reproductive success. Proceedings of the Royal Society of London B: Biological Sciences 279:4845-4852.

Andow, D.A. 1991. Vegetational diversity and arthropod population response. Annual Review of Entomology 36:561-586.

Andow, D.A. and S.J. Risch. 1985.

Predation in diversified agroecosystems: Relations between a Coccinellid predator Coleomegilla maculata and its food. Journal of Applied Ecology 22:357372.

Cohen, S.Z. 2010. Urban pesticide risk assessment and risk management: Get involved. Environmental Toxicology and Chemistry 29:1201-1202.

Crawley, M.J. 1997. Plant Ecology. 2nd ed. Malden (MA): Blackwell Publishing.

Fiedler, A.K., D.A. Landis, and S.D. Wratten. 2008. Maximizing ecosystem services from conservation biological control: The role of habitat management. Biological Control 45:254 271.

Frank, S.D. 2010. Biological control of arthropod pests using banker plant systems: Past progress and future directions. Biological Control 52:8-16.

Free, J.B. 1993. Insect Pollination of Crops. 2nd ed. San Diego (CA): Academic Press.

Hillock, D. and B. Simons. 2002. Oklahoma Garden Planning Guide. HLA-6004. Stillwater (OK): Oklahoma State University Cooperative Extension Service.

Hoback, W.W., T.M. Svatos, S.M. Spomer, and L.G. Higley. 1999. Trap color and placement affects estimates of insect family-level abundance and diversity in a Nebraska salt marsh. Entomologia Experimentalis et Applicata 91:393-402.

Hooks, C.R.R. and M.W. Johnson. 2003. Impact of agricultural diversification on the insect community of cruciferous crops. Crop Protection 22:223-238.

Isaacs, R., J. Tuell, A. Fiedler, M. Gardiner, and D. Landis. 2009. Maximizing arthropod-mediated ecosystem services in agricultural landscapes: The role of native plants. Frontiers in Ecology and Evolution 7:196-203.

Johansen, C.A. and D.F. Mayer. 1990. Pollinator Protection: A Bee and Pesticide Handbook. Cheshire (CT): Wicwas Press. Kearns, C.A. and D.W. Inouye. 1993. Techniques for Pollination Biologists. Niwot (CO): University of Colorado Press.

Kloen, H. and M.A. Altieri. 1990. Effect of mustard (Brassica birta) as a non-crop plant on competition and insect pests in broccoli (Brassica oleracea). Crop Protection 9:90-96.

Landis, D.A., F.D. Menalled, A.C. Costamagna, and T.K. Wilkinson. 2005. Manipulating plant resources to enhance beneficial arthropods in agricultural landscapes. Weed Science 53:902-908.

Landis, D.A., S.D. Wratten, and G.M. Gurr. 2000. Habitat management to conserve natural enemies of arthropod pests in agriculture. Annual Review of Entomology 45:175-201.

Nicholls, C.I. and M.A. Altieri. 2004. Designing species-rich, pest-suppressive 
agroecosystems through habitat management. In: Agroecosystems Analysis. D. Rickerl and C. Francis (eds.). Madison (WI): American Society of Agronomy.

Pimentel D., H. Acquay, M. Biltonen, P. Rice, M. Silva, J. Nelson, V. Lipner, S. Giordano, A. Horowitz, and M. D'Amore. 1992. Environmental and economic costs of pesticide use. Bioscience 42:750-760.

Ponti, L., M.A. Altieri, and A.P. Gutierrez. 2007. Effects of crop diversification levels and fertilization regimes on abundance of Brevicoryne brassicae (L.) and its parasitization by Diaeretiella rapae (M'Intosh) in broccoli. Agricultural and Forest Entomology 9:209-214.

Potts, S.G., B. Vulliamy, A. Dafni, G. Ne'eman, and P. Willmer. 2003. Linking bees and flowers: How do floral communities structure pollinator communities? Ecology 84:2628-2642.

Potts, S.G., B. Vulliamy, S. Roberts, C. O’Toole, A. Dafni, G. Ne'eman, and P.G. Willmer. 2004. Nectar resource diversity organizes flower-visitor community structure. Entomologia Experimentalis et Applicata 113:103-107.

Rebek, E.J., C.S. Sadof, and L.M. Hanks. 2005. Manipulating the abundance of natural enemies in ornamental landscapes with floral resource plants. Biological Control 33:203-216.

Rebek, E.J., C.S. Sadof, and L.M. Hanks. 2006. Influence of floral resource plants on control of an armored scale pest by the parasitoid Encarsia citrina (Craw.) (Hymenoptera: Aphelinidae). Biological Control 37:320-328.

Relyea, R.A. 2009. A cocktail of contaminants: How pesticide mixtures at low concentrations affect aquatic communities. Oecologia 159:363-376.

Sadof, C.S., R.J. O’Neil, F.M. Heraux, and R.N. Wiedenmann. 2004. Reducing insecticide use in home gardens: Effects of training and volunteer research on adoption of biological control. HortTechnology 14:149-154.

Tuell, J.K., A.K. Fiedler, D.A. Landis, and R. Isaacs. 2008. Visitation by wild and managed bees (Hymenoptera: Apoidea) to Eastern U.S. native plants for use in conservation programs. Environmental Entomology 37:707-718.

Turcotte, M.M., C.J.M. Thomsen, G.T. Broadhead, P V.A. Fine, R.M. Godfrey, G.P.A. Lamarre, S.T. Meyer, L.A. Richards, and M.T.J. Johnson. 2014. Percentage leaf herbivory across vascular plant species. Ecology 95:788.

U. S. Environmental Protection Agency. 2011. Pesticides industry sales and usage market estimates 2006 and 2007. http://www.epa.gov/opp00001/pestsal es/ (1 October 2012).

U. S. Environmental Protection Agency. 2009. Updated review of Malathion incident data. Docket EPA-HQ-OPP2009-0317-0004.

http://www.regulations.gov/search/Re gs/home.html\#docketDetail? R=EPAHQ-OPP-2009-0317 (1 October 2012). Zangerl, A.R., J.G. Hamilton, T.J. Miller, A.R. Crofts, K. Oxborough, M.R. Berenbaum, and E.H. de Lucia. 2002. Impact of folivory on photosynthesis is greater than the sum of its holes. Proceedings of the National Academy of Sciences 99:1088-1091.

Zar, J.H. 1999. Biostatistical Analysis. 4th ed. Upper Saddle River (NJ): Prentice Hall. 